\title{
Enhancing intercultural competence through U.S. multicultural literature in the EFL classroom
}

\author{
Desarrollo de la competencia intercultural mediante \\ la literatura multicultural de USA en la clase de inglés
}

Luis Fernando Gómez Rodríguez ${ }^{1}$

\section{Abstract}

This article reports part of an action research experience that was conducted in an advanced EFL classroom of the language program at a public university in Bogotá, Colombia in 2011. The study proposes the incorporation of authentic multicultural literary texts in the EFL classroom as a means to develop intercultural communicative competence (ICC). Data were collected to show how learners acquired cultural knowledge, developed critical intercultural skills, and created positive attitudes -aspects of Byram's model of ICC-when they read literary short stories. Findings show that integrating language and literature in EFL constitutes a pedagogical contribution to construct critical intercultural awareness.

Key words:

intercultural communicative competence, authentic texts, multicultural literary texts, knowledge, attitudes, skills.

\section{Resumen}

Este artículo informa parte de una experiencia de investigación acción llevada a cabo en una clase de inglés avanzado del programa de lenguas de una Universidad Pública en Bogotá, Colombia en el 2011. El estudio propone la incorporación de textos literarios multiculturales en el contexto de inglés como lengua extranjera como medio para desarrollar la competencia comunicativa intercultural (CCI). Los datos recolectados demuestran cómo los estudiantes adquirieron conocimiento cultural, desarrollaron habilidades críticas y crearon actitudes positivas -aspectos del modelo de CCI propuestos por Byram- cuando leyeron cuentos literarios. Los resultados muestran que la integración del lenguaje y la literatura en EFL constituye un aporte pedagógico para construir conciencia intercultural crítica.

\section{Palabras clave:}

competencia comunicativa intercultural, textos auténticos, textos literarios multiculturales, conocimiento, actitudes, habilidades.

1 Full time teacher at Universidad Pedagógica Nacional. He holds a B. A. degree in English and Spanish from Universidad Pedagógica Nacional (UPN), a M. A. in education from Carthage College, USA, and a Ph.D. in English Studies from Illinois State University, USA. E-mail: Ifgomez@edagogica.edu.co. 
Our contemporary world is becoming a globalized society as people from over the world are becoming aware of the need to establish cross-cultural relationships. Cai (2000) and Banks (2004) state that new generations need to cross cultural borders in order to fit into a pluralistic world because the political and economic aspects of globalization are transforming national borders among nations. Kashru (1992) recognizes that globalization will result in the further spread of English as an international language because more people around the world learn English as a requirement of international communication. This process has great implications for English language education, one being of main importance the link between language and culture. Culture remains an integral part of language learning because English is a relevant means to help learners develop their intercultural awareness as they are able to discover underlined cultural manifestations among their own and other people's background.

In view of exploring how language and culture can be enhanced in the EFL classroom, this article argues that one potential means to help EFL learners to develop intercultural communicative competence (ICC) at a critical level is multicultural literature, a significant resource that might prepare students to become critical intercultural beings in this globalized society. This exploration is based on an action research procedure carried out in 2011, intending to observe how a group of advanced EFL learners at a public University in Bogotá developed ICC through the critical reading and discussion of American multicultural literary short stories.

\section{Statement of the problem}

Although there are many teaching approaches to help EFL learners to attain communicative competence in English, EFL instruction in the Colombian context, as well as in many other countries, still lacks the inclusion of ICC because classes mainly focus on the study of language forms and communicative functions. Barletta (2009, p. 143) affirms that "educators have found themselves with a limited notion of culture and culture teaching within the communicative approach" because of misconceptions about the teaching of communicative competence. The teaching of culture has occupied a secondary place, even though there is acceptance of the need to integrate language and culture in many language departments. Byram (1997), Lázár (2003), and Dogankay-Aktuna (2005) assert that the attainment of ICC has been poorly developed because EFL instruction continues giving more importance to the study of the grammatical level of English than to the cultural implications involved in language production.

Because of this major limitation that exists in many EFL contexts, as it happens in Colombia, this research proposes the incorporation of authentic multicultural literary texts of the U.S. in the EFL classroom as a means to enhance learners'critical ICC. Many teachers and students still need to be more aware that language learning goes far beyond the ability to use the linguistic code in order to communicate. It is also an opportunity to attain critically cultural knowledge, to develop skills to deal with different cultural issues, and to create positive attitudes to respect differences.

\section{Research question}

The research question guiding the study is based on Byram's model of ICC which I will address in the theoretical framework: Byram states that ICC development is mediated by the enhancement of knowledge, skills, and attitudes. In light of these factors, how might EFL advanced learners develop critical ICC through the study of multicultural literary selections?

\section{Theoretical framework}

\section{Notion of culture}

In order to understand ICC, it is important to define culture. One useful definition is given by SpencerOatey (2008, p. 9) who says that culture is "a fuzzy set of basic assumptions and values, orientations to life, beliefs, policies, procedures, and behavioural conventions that are shared by a group of people, 
and that influence (but do not determine) each member's behaviour and his/her interpretations of the 'meaning' of other people's behavior." This definition claims that a group of people who share basic values and conventions might be inclined to accept them, but not necessarily agree with, approve, and/ or follow them in strict terms. Individuals might be "influenced" by the status quo of their culture, but not completely dependent of it, and this means that members of a cultural group are likely to transform engrained cultural meanings.

In the EFL area, elements of culture have generally been seen as static, representative, and homogeneous because learners and teachers tend to create stereotypes and generalizations of a cultural group. Recently, culture is being viewed by EFL scholars as dynamic and variable because they have started to recognize that culture is constantly changing due to the fact that the members of a given community display different behaviors and attitudes toward the established values and construct, and change cultural meanings through social interaction and communication. Paige, Jorstad, Siaya, Klein \& Colby (2003) recognize that it is not enough to accept static definitions of culture because language and cultural patterns change over time according to the happenings a community goes through and to the influence of some cultures on others. Trujillo (2002) sees culture as a dynamic entity in a continuous process of transformation that is transmitted and reshaped through generations.

Despite some recent view of culture, involving the transformation of society's ideologies and beliefs, Atkinson (1999, p. 626) affirms that there has been little attention to the notion of culture in EFL because this field has adopted a "received view" of culture characterized by a "geographically distinct" entity, "relatively unchanging, and homogeneous," and as a system of rules that "substantially" determine individuals' behavior. In consequence, Atkinson recognizes the importance of adopting a transformative and "nonstandard" view of culture in the EFL area in which concepts of identity, hybridity, power, difference, and resistance become essential to redefine the traditional view of culture.

\section{Intercultural communicative competence (ICC)}

Interculturality involves the mutual understanding of differences when individuals from different backgrounds meet together. Interculturality is increasingly visible in the modern world as more and more people establish different relationships, trades, or communication with diverse communities. Interculturality (Trujillo, 2002) intends to resist ethnocentrism, is grounded on the recognition and respect of individuals' nationalities, and involves participating in communication to accept diversity. The views of culture and interculturality facilitate the understanding of ICC which is "the ability to interact with 'others', to accept other perceptions of the world, to mediate between different perspectives, [and] to be conscious of their evaluations of difference" (Byram, Nichols, Stevens, p. 5, 2009).

Byram (1997, p. 34) explains that ICC consists primarily of three main aspects: the first one is knowledge about "social groups and their products and practices in one's own and in one's interlocutor's country, and of the general processes of societal and individual interaction." Knowledge involves being conversant with aspects such as beliefs, historical relationships, emblematic characteristics of a group, its religious values, etc. It emphasizes the recognition of "cultural products," including written "documents" such as literary texts as a means to acquire knowledge because "products" and "documents" always engage deep cultural issues.

The second aspect Byram proposes for ICC development is skills, which he subdivides into the skill of interpreting, the skill of relating, and the skill of discovering. These skills imply the fact that becoming intercultural is not just to be understanding and tolerant to differences, but to become critical to them (that is why my emphasis on critical ICC). For instance, Byram notes that the skill of interpreting confronts the individual, coming across a "document" produced by a cultural group, to assume a position and explain the meaning or make sense of a given situation or document. This skill necessarily depends on the skill of relating as Byram argues that the ability to interpret a document, let's say for ins- 
tance, a literary text, depends on knowledge of one's own and the other environment. Thus, interpreting a document or a cultural situation inevitably involves establishing relationships by identifying common or uncommon grounds; in other words, creating intercultural knowledge.

The skills of interpreting and of relating equally connect to the skill of discovery. When an individual is able to make sense of something new as he/she relates it to his/her existing knowledge, he/she discovers newness or something he/she did not know before. The skill of discovery (Byram, 1997, p. 38) implies "building up specific knowledge as well as the understanding of the beliefs, meanings, and behaviors which are inherent in particular phenomena, whether documents or interactions." From this perspective, learners need to develop these three skills to be able to acquire ICC.

Following the aspects of knowledge and skills, the third aspect involved in the attainment of ICC is the ability to create positive attitudes such as openness, empathy, tolerance, readiness, and curiosity for cultural expressions that may be similar and even strange from our own. These attitudes oppose to popular negative attitudes as prejudice and intolerance which very often cause cultural misunderstanding among people from diverse backgrounds. Hence, individual of a cultural community need to be willing to analyze their own meanings from the viewpoint of others in order to engage in crosscultural communication. With the acquisition of these three aspects, individuals not only get prepared to deal with other groups different from their own, but become more critical to understand why differences exist.

Knowledge, skills, and attitudes, as proposed by Byram, help learners to foster a savoir known as critical cultural awareness which is the ability to evaluate critically the similarities and differences of the members of the own and the foreign cultures, as well as their practices, ideologies, and products individually and collectively because total cultural homogeneity does not exist. In this sense, the intercultural speaker becomes critical when he/she "brings to the experiences of their own and other cultures a "rational and explicit standpoint from which to evaluate" (1997, p. 54).

ICC model can be articulated with what Kubota (2004) calls liberal multiculturalism which she defines as a deeper critical understanding of diverse cultures through which learners interrogate issues of inequality, race, gender, and class in specific ideological and political contexts. Kubota argues that liberal multiculturalism is that which intends to raise students' conscious awareness about unfair social practices and oppression. By helping EFL learners understand social inequality they can become active agents for social change. She believes that education needs to address issues of equality and cultural transformation in language learning as learners are invited to discover that social realities are dynamic, heterogeneous, and rooted in unjust historical and political contexts. Kubota recognizes that current approaches and practices in language teaching paradoxically eliminate the possibilities to promote cultural diversity. That is why she claims for engaging students in critical learning about cultural and linguistic diversity as well.

Kubota's idea of helping language students to become critical in order to transform society encompasses the skills of interpreting, relating, and discovering proposed by Byram's definition of ICC. Instead of celebrating in a naïve way the fact that all human beings are different, learners need to interpret and analyze critically why being "different" or coming from other communities is not generally valued and why there are negative attitudes of exclusion and discrimination as well as relations of power and hegemony. When learners acquire thinking skills, analytical knowledge, and positive attitudes, they are not only able to become more receptive and understanding about the cultural meanings of other groups, but capable of breaking stereotypes and simplified representation of diverse communities.

\section{The inclusion of literature in EFL}

As a cultural expression, literature not only contributes to transformation of culture through time, 
but can help students to become critically intercultural individuals. Several scholars such as Carter \& McRae (1996), McKay (2001), and Amer (2003) agree that teaching literature in the EFL setting can contribute enormously to the learning process of students in two main emphases. First, through literature students can improve their language competence because literature is authentic language in use. Second, literature is a means through which students can acquire literary knowledge and reading and interpretative skills through the negotiation of multiple meanings.

Likewise, Carter \& Long (1991) and Amer (2003) have emphasized a shared argument: literature can act as a powerful agent to develop students' intercultural awareness while at the same time nurturing empathy for diversity as they understand cultures and ideologies different from their own in time and space. All these assertions indicate that literature has been recognized by a growing body of contemporary scholarship as a meaningful resource to foster ICC in the EFL context, a material that many EFL teachers have been reluctant to use in the language classroom. The Common European Framework of References to Languages (2001) also advocates that an excellent way to promote pluriculturalism in the classroom is through aesthetic uses of language, including the production, reception, interaction, or mediation of oral or written literary language. If real critical ICC should be one of the goals to be achieved in second language learning, the use of literature could me an effective alternative.

\section{Teaching approaches to study literature in the EFL classroom}

\section{Equity pedagogy}

Since this study proposes the development of critical ICC through the reading of literary texts, I decided to use two teaching approaches implemented in multicultural education that were suitable to achieve this purpose in the EFL context. These two approaches, Interaction of Contact Zones and Engagement in Debate, aim at helping students to become critically intercultural beings. These approaches are influenced by one recent pedagogical tendency in the field of multicultural education called equity pedagogy. McGee and Banks (1995) explain that equity pedagogy refers to teaching strategies and classroom environments that help students from diverse cultural backgrounds to acquire the appropriate knowledge, skills, and attitudes to deal successfully within a pluralistic society. Interestingly, this definition relates to Byram's argument who asserts that knowledge, skills, and attitudes are crucial components of ICC. McGee and Banks (1995, p.152) explain that the definition of equity pedagogy not only suggests helping students become aware of cultural aspects, but "become reflective" and endowed with skills to turn into "effective agents for social change." Banks indicates that citizens in a diverse globalized society should be reflective to change the world and make it more just and democratic. Equity pedagogy provides a useful rubric for describing the use of different teaching approaches to meet the diverse needs of EFL students and to prepare them to acquire the three main components of ICC at a critical level through the reading of literary works.

Although scholars who propose Interaction of Contact Zones and Engagement in Debate do not identify themselves as proponents of equity pedagogy, this term seems to work well for illustrating similar teaching goals and procedures shared by these two approaches. Whether or not every author would label themselves as proponents of equity pedagogy, my intention of putting their diverse, but similar pedagogical findings under equity pedagogy in this research study is to demonstrate that their pedagogical proposals aim at helping students become critical agents of fair social change in pluralistic societies.

\section{Contextualization of Contact Zones}

This teaching approach has been described by Pratt (2002) as sites of intercultural encounter and "social spaces where cultures meet, clash, grapple with each other, often in contexts of highly asymmetrical relations of powers such as colonialism, slavery, or their aftermath as they are lived out in many parts of the 
world today" (p. 4). The notion of contact zones can be brought to teaching and learning contexts. Pratt proposes that the learning process works better when there is space for students to engage in oppositional discourse, resistance, and critique instead of giving major emphasis to the teacher's point of view. She suggests that the classroom should be imagined as functioning not like a "homogeneous community," but as a site of contact zones where students from different origins and with different experiences can interact, resist, and/or criticize the material being studied. The notion of contact zones refers to moments when the literary texts relate to some students' specific historical or personal experiences based on the fact that difference is a fundamental reality among individuals.

Recognizing classrooms as contact zones seems to be an ideal means to develop critical ICC. The diverse literacies that students bring to the classroom can be treated as resources for establishing mutual recognition and construct cultural knowledge through collaborative learning based on the discussion that students bring into the contact zones. Creating opportunities for constructive participation in contact zones seems to enable students to cope with their own cultural background in interaction with the cultural background of other members. That is to say, difference is not treated as an obstruction, but as a valuable learning tool.

Since the language classroom is a context in which EFL learners are learning English and are faced to learn the culture of another community, the EFL classroom can be a social space where learners meet with the realities of a multicultural and globalized world, which can itself invoke awareness of the diversity of their home and classroom. I suggest that EFL learners can be engaged in the reading of stories to identify the ideas, historical events, ideologies, and attitudes of different cultural groups through appropriate literary texts and how authors react in favor on against those ideologies.

\section{Engagement of Debate and Conflict in the Classroom}

Engaging students in debate and conflict in the classroom is proposed by Hames-Garcia (2003). He points out that teachers are influenced by the regulations of what he calls a "congratulatory" approach which evades critical thinking. "congratulatory" teaching of literature and culture refer to the idea that contents are studied and analyzed in sympathetic and even idealistic terms, missing out the objective truth about the real history and ideologies authors show. Debate and conflict in the classroom is to enable them with the possibility to make critical evaluations about cultural conceptions and acquire full understanding of social problems, oppressions, and affairs of the world from a more realistic perspective. The teacher's central goal is not always for everyone to agree; it is about listening to what others have to say and exploring divergent positions.

Critical debate as a teaching strategy can also be applied in the EFL classroom when reading literary texts, because debate implies the negotiation of meaning as learners discuss critically different points of view and construct knowledge through an authentic communicative dialogue. As a negotiator, the EFL learner can get involved in an exchange of ideas through debate who, according to Kramsch (2001), "has the potential of putting in question the status quo" (p. 29). The learner can question traditional cultural situations as he/she becomes a critical evaluator through the study of multicultural issues. Kramsch claims language teachers' responsibility is not only to "entertain," but also "challenge" and put in question traditional views and attitudes. Engagement of debate can also occur in the language classroom as a means to re-evaluate unjust attitudes and naïve "celebratory" views of the world when learners are exposed to the study of literary texts.

\section{Literary texts selected for the research}

I decided to have my students read three literary selections of U.S. multicultural literature. The pedagogical reasons for selecting this type of literature is that, first, through multicultural literature students can expand the knowledge of the world as they are exposed to identify, compare, and contrast the differences and similarities between their cultural background and those of other groups. Second, through multicultural literature students can reduce prejudi- 
ces and stereotypes. Cai (2000) claims ignorance and prejudices are two main obstacles that block mutual understanding and respect among diverse cultural groups. In order to reduce prejudices and attitudes and discriminatory attitudes, students need more culturally specific books that give readers insights into cultures other than their own. (Table 1)

The study of each story took two weeks due to the fact that, through a close reading model, participants read the stories, studied new language, and understood the author's ideas and literary implications in a careful way. When reading the stories, students discussed the immigration experience in the U.S. of Latinos, Africans, and Jews, the intersection between American and Chicano, Jewish, and Latino cultures, the search of the American Dream, and the similarities/differences among these three ethnicities and their Colombian cultural traditions, hence, promoting ICC. To discuss these topics, students were given study guides that included (1) reading comprehension activities to determine students' level of understanding and knowledge of vocabulary, (2) activities to identify the author's literary ideas and the themes in each story; and (3) activities of deep interpretations, which contained questions that activated students' critical opinions and evaluations about the characters, actions, and meanings of the stories. Learners worked in small groups to compare their views through a process of negotiation of meaning and explored how the stories challenged the status quo of established cultural traditions.

\section{Research design}

With the previous theoretical framework and pedagogical stances, I implemented a qualitative research type in order to inquire how a group of EFL learners at UPN could foster critical ICC through multicultural literary selections. This was essentially action research which looked deeply at a small group of individuals and drew conclusions about that particular group in that specific context. Therefore, the purpose of my study was not to test any hypotheses, but rather to explore and establish the outcomes that were generated from the implementation of my pedagogical proposal.

\section{Data collection instruments}

To answer the research question, I focused on a holistic approach through observations as I took field notes every class about students' interaction with the literary texts and what aspects of ICC they developed during the reading and class discussion. I also collected three journals from students in which

Table 1. U.S. multicultural short stories read in the course literature Anglophone 1.

\begin{tabular}{|c|c|c|c|c|}
\hline Ethnicity & Author & $\begin{array}{l}\text { Short } \\
\text { Story }\end{array}$ & $\begin{array}{l}\text { Teaching ap- } \\
\text { proach }\end{array}$ & characters / intercultural themes \\
\hline $\begin{array}{l}\text { U.S. } \\
\text { Mexican- } \\
\text { American }\end{array}$ & $\begin{array}{c}\text { Sandra } \\
\text { Cisneros }\end{array}$ & $\begin{array}{l}\text { "Woman } \\
\text { Hollering } \\
\text { Creek" }\end{array}$ & $\begin{array}{l}\text { Contextualization } \\
\text { of contact zones }\end{array}$ & $\begin{array}{l}\text { Cleófilas is abused by her chauvinist husband. She is a vic- } \\
\text { tim of domestic violence and the impositions of a patriarchal } \\
\text { society. To evade her submissive reality, she watches soap } \\
\text { operas/lt deals with the situation of Chicanas living in the U.S. }\end{array}$ \\
\hline $\begin{array}{l}\text { Jewish- } \\
\text { American }\end{array}$ & $\begin{array}{l}\text { Bernand } \\
\text { Malamud }\end{array}$ & $\begin{array}{l}\text { "The First } \\
\text { Seven } \\
\text { Years" }\end{array}$ & $\begin{array}{l}\text { Contextualization } \\
\text { of contact zones }\end{array}$ & $\begin{array}{l}\text { Feld wants his daughter Miriam to marry the man of his choi- } \\
\text { ce, not hers. She is in love with Sobel, an underprivileged } \\
\text { Jewish immigrant. } \\
\text { Themes of discrimination, materialism, cultural identity, and } \\
\text { problems of generation gaps. } \\
\text { Conflict between Jewish and American cultures. }\end{array}$ \\
\hline $\begin{array}{l}\text { African- } \\
\text { American }\end{array}$ & $\begin{array}{l}\text { Alice } \\
\text { Walker }\end{array}$ & $\begin{array}{l}\text { "Everyday } \\
\text { Use" }\end{array}$ & $\begin{array}{l}\text { Engagement of } \\
\text { Debate and Conflict } \\
\text { in the Classroom }\end{array}$ & $\begin{array}{l}\text { Dee, an educated girl, looks down on her mother and her sis- } \\
\text { ter Maggie who live in the countryside. Dee has lost respect } \\
\text { for her African-American heritage. She visits her family and } \\
\text { wants to take by force the family quilts to decorate her new } \\
\text { apartment. She also disrespects her mother. Conflicts of cul- } \\
\text { tural loss and social class. }\end{array}$ \\
\hline
\end{tabular}


they reported their experience with each literary piece. Students were asked to write a journal after the literary analysis of each story was completed. I also collected their response papers (artifacts) about the analysis of the stories which took place once students had shared their opinions orally with the whole class. Those responses consisted of answering a question of what had been debated in class so that they provided their own views and conclusions individually based on the class discussion. Additionally, I used a semi-structure interview at the end of the pedagogical intervention in which I inquired what intercultural knowledge participants had learned and which skills they had developed through the whole experience. Since this was a qualitative research study, the whole procedure consisted of observing and knowing participants' reactions, responses, and opinions about the knowledge, skills, and attitudes they personally fostered when reading multicultural short stories. Qualitative research (Stake, 2010) seeks people's points of view, perceptions, and understanding. It also takes verbal forms, including qualitative judgments and meaningful communicative patterns from the perceptions of those from whose lives the data are drawn (Candlin and Hall, 2002).

\section{Participants}

23 seventh semester female and male participants were involved in my study who registered for my course Literatura Anglófona 1 in the first term, 2011. They were adults, aged 18 to 22 . They had already taken six previous English courses in the undergraduate program called Lengua y Cultura Anglófonas. Each course consisted of 8 hours weekly. Additionally, they had taken two English writing courses. In those English courses, they had worked with the communicative textbook Top Notch, which is a six-level course for international communication. These students had also been given adapted and short versions of reading materials, and authentic reading from newspapers, magazines, and the Internet, but had never been provided with authentic readings of North American literary productions. To protect students' identity, I assign them a fictitious name.

\section{Data analysis}

After the pedagogical intervention, I did a qualitative analysis of the data gathered from the participants and observations. Data came from participants' comments and opinions and field notes of their awareness to develop ICC in the literature classroom. I analyzed data according to a coding process (Patton, 2002), a technique used to organize the data collected during the pedagogical experience. The purpose of this process was to find similar information generated from all participants involved in the research. By using the grounded approach method (Freeman, 1998), I read and examined the data gathered several times in order to triangulate it. I grouped participants' frequent and similar comments that were often present in the different data collection instruments in regard to the components of intercultural communicative competence: the knowledge, skills, and attitudes they enhanced during the readings of multicultural literature.This comparative triangulation assures the internal validity of the research process. In this sense, units of analysis became frequent patterns shared among the participants. Units of analysis allowed me to formulate themes. In other words, from students' critical reflections about one aspect of ICC, I formulated a theme in such a way that those themes globally represented those common critical reflections.

\section{Findings}

According to EFL learners' opinions, these are the themes related to the development of ICC in an EFL classroom through the study of multicultural literary texts. (Table 2).

\section{Themes related to the aspect of knowledge}

\section{a. The literary texts depict unequal social differen- ces and gender roles in social and family settings through the characters' interactions.}

Field notes show that participants acquired knowledge about social and gender roles differences in the multicultural stories. They were able to recognize that the stories focused on prejudicial treatment of individuals based on race, social con- 
Table 2. Themes that emerged from data analysis.

\begin{tabular}{l}
$\begin{array}{l}\text { The literary texts depict unequal social differences and gender roles in social and family settings through } \\
\text { the characters' interactions. }\end{array}$ \\
$\begin{array}{l}\text { Knowledge } \\
\text { The literary texts provide the means to learn about traditions and customs from diverse ethnic back- } \\
\text { grounds. } \\
\text { Class discussion allows learners to discover cultural content reflected in the multicultural reading (skills } \\
\text { of discovery). }\end{array}$ \\
$\begin{array}{l}\text { Learners were able to interpret cultural, literary, and other kinds of content when reading multicultural } \\
\text { texts (skill of interpreting). }\end{array}$ \\
$\begin{array}{l}\text { Learners were able to compare cross-cultural and literary contents when reading multicultural texts (skill } \\
\text { of comparing). }\end{array}$ \\
\hline Attitudes
\end{tabular}

dition, economic position, and gender roles. For example, a case of unequal social differences were commented by learners with the short story "The First Seven Years." One student pointed out that Sobel, one of the characters, suffered from exclusion just because he was poor and Jewish. In her opinion, Sobel has been excluded by Germans for being Jewish, by Americans for being an immigrant, and now by Feld (a Jewish man) for being poor and uneducated. Something that impressed this student the most was that Sobel was excluded by Feld, who was also Jewish (field notes, April 28, 2011). In that sense, the student recognized through the story that in many occasions we exclude people fromour own or different cultural backgrounds because we depend on unjust prejudices. From interviews, there are the following similar opinions:

[Felipe] I havelearned about the situation of Jewish immigrants during the Second World War when they came to the U.S. Immigrants saw the U.S. as a land of opportunities. (Interview, May 31, 2011)

[Adriana] In "The First Seven Years," the author shows how the economic situation affected immigrants in the II World War, and what the author was experiencing as being Jewish himself. I saw the effects of materialism in the life of the characters. (Interview, May 31, 2011)

Unequal gender roles were also addressed when EFL learners read "Woman Hollering Creek."
According to filed notes (April 26, 2011), one learner argued that Juan Pedro's violent treatment to Cleófilas, the main characters in the story, is a vivid representation of Latin American males who disregarded their wives just because they were women. Based on the perspective proposed by contextualization of contact zones, another learner stated that Cleófilas represented the case of many submissive women in many Latin American countries who were forced to obey their husbands' impositions and accept their infidelities. Students reflected critically about several examples provided in the story that show the unequal gender roles between men and women: Cleófilas had to cook, clean, and take care of her baby while her husband spent his time drinking beer in a bar. Men had the power to give orders and beat their wives while women had to obey. Students' response papers also show learners critical comments about gender roles and relations of power:

Despite the role of women as wives and as mothers have changed in last decades in many societies, there is still a Patriarchal culture in which man is the dominant figure. That is to say, the chauvinist Latino culture prevails, and the woman is submitted to man's will. Cleófilas is a submissive wife who is abused by her husband, but who does not do anything to change her situation, and she resigns herself. (Taken from students' response papers, April 28, 2011) 
This response shows how participants were able to produce personal critical views about the situation of women in Latin American societies and aboutthe situation of Cleófilas as an immigrant woman in the U.S. from the multicultural piece they had read. Interestingly, these learners gave their personal opinions about social and cultural topics in the target language, a challenging task for them. If we take into account that they are in the process of learning English as a foreign language, they were actually doing a great performance to become critical readers and to enhance the aspect of knowledge of ICC. The analysis of this theme that emerged from the data collected confirms the fact that learners acquired knowledge through multicultural literary works studied in the EFL.

\section{b. The multicultural literary texts provide the means to learn about traditions and customs from diverse ethnic backgrounds.}

This theme emerged from the frequent opinions learners gave about cultural traditions. Data show that students analyzed important and unique traditions including in the short stories. For instance, with the story "The First Seven Years," learners discussed that the father, who was Jewish, wanted to impose a husband on his daughter Miriam because it was part of his strict Jewish traditions. By contrast, his daughter, who was more adapted to the American lifestyle, wanted to be independent, since she intended to release from her imposed Jewish traditions in order to marry the man she was in love with. This idea was developed by one of the students when he stated that "the story presents the struggle of cultural ideologies between Feld (the father) and his daughter Miriam" (field notes, April 28, 2011). This example shows that students were able to recognize and appreciate critically diverse traditions and beliefs among diverse cultural settings that transform and challenge the status quo, as learners started to realize that the U.S. is not a monocultural nation, but the mixture of various ethnic groups.

When reading "Everyday Use," learners noticed that Mama, the main character, was proud of her countryside life as she lived in a modest house where she used to carry pots to bring water to her house. One learner said that Mama used to live a life based on simplicity and in contact with nature because she still depended on her ancient AfricanAmerican traditions and as she had been raised in the past (field notes, May 19, 2011). Another learner explained that Maggie, Mamma's daughter, knew the history of the utensils of her house, including the dasher and the chairs her father had made for the house, in contrast to her sister Dee who did not care about the historical value of those objects in her family. By referring to this part of the story, the student argued that Maggie was very knowledgeable about her family ancestors and African-American traditions (taken from field notes, May 19, 2011). Moreover, some learners discussed that Dee and Mama have different views about heritage and culture. Dee wanted to have the family quilts made by her African-American ancestors to be hung on the wall of her new apartment as decorative souvenirs, while, for Mama, the quilts represented objects for daily use such as to warm family members (field notes, May 19, 2011).

The discussion on the meaning of the quilts also arose other related issues as learners started to consider who deserved them: whether Dee (the educated daughter who had left home for a long time and had denied her past), or Maggie (the helpful daughter who had stayed with her Mama and had embraced her African-American traditions). Through engagement and debate in the classroom, learners expressed their critical opinions and, after discussion was held, they concluded that Maggie deserved the quilts. Engagement in debate became an ideal means to discuss deep cultural traditions of other backgrounds (field notes, May 19, 2011). Significant data gathered from students' response papers also show that learners reflected about the quilts as important cultural elements in African traditions:

Maggie and her mother [...] want to keep the quilts in order to preserve the traditions of their family. This is expressed when Mama says, "Maggie knows how to quilt." Quilting is an important aspect for that family because it means to carefully make the quilts by hand and to contribute to pass on their own traditions. Moreover, they need to 
keep their African-American tradition by using the quilts for "everyday use." That is, putting them on bed, using them daily, and seeing them every day are ways to demonstrate that the quilts are important because all the generations and the traditions of the family will never be forgotten.

(Maria’s response paper, June2, 2011)

In these fragment, the learner discussed the importance of African-American traditions such as marriage and family union as acceptable values that are passed on through quilting. This response shows evidence of the new kind of critical cultural knowledge they acquired when reading "Everyday Use," knowledge that they did not know before. Interviews equally reveal students' acquisition of intercultural knowledge of traditions as this comment states:

[Danilo] (S6) I think that through the AfricanAmerican literary works I learned about the roots of black people. I think that the discussion of "Everyday Use" was very important to understand heritage and what black people think of their own situation living in the U.S. (Interview, May 31, 2011)

When learners read "Woman Hollering Creek," they also acquired knowledge about MexicanAmericans by applying the principles of contextualization of contact zones. Although there are many similarities between Colombian and Mexican, and Mexican-American cultures because they are Latinos, learners still were able to identify cultural aspects that are more ingrained and deep-rooted in the Mexican heritage. One clear example taken from field notes (May 19, 2011) is that students discussed the influence of Mexican soap operas (an element that appears in the story) on the life of many Mexican women. In learners' opinion, soap operas are ridiculous, but dangerous because they preserve the traditional belief that men must be chauvinist and women have to be submissive. Another learner said that most of the female characters in Mexican soap operas suffer from poverty, humiliation, and abandonment, and hope to finish with those problems by falling in love with a rich and handsome man who can save them from pain. Thus, women are pictured as dependent on men's power as it hap- pened in Cisneros's short story. That is, the cultural message of many Latino communities is that women can only find happiness by just getting a man. Other participants argued that Mexican soap operas are a negative influence in the Latino culture because they intend to promote an idealistic and conformist conception that marital state is the greatest and happiest achievement in women's life. From these views, learners concluded that Cisneros wanted to criticize soap operas made in her home country by not only showing the negative effect they have on Cleófilas's life in the short story, but on Mexican women in general since, through history, Mexico has accepted soap operas as an important product of their cultural development. Thus, students analyzed, agree, and disagree with imposed cultural constructs of patriarchal societies.

Students' response papers also show how they provided a critical view in regard to the influence of soap operas in the Latin American culture:

Soap operas have been one of the most successful products of Mexican television. Soap operas became so famous that they soon conquered Latin American audience, building up the identity of Latino society. However, soap operas have been criticized because they show a Manichaean vision of life represented through the characters: The main character is pure, kind, and spotless, almost perfect while the antagonist character is the incarnation of evil [...] Cleófilas who is influenced by Mexican soap operas, gets married to Juan Pedro, but he starts to mistreat her. Then, she sees that her life is not as perfect as she dreamed of having when watching soap operas [...] Cleófilas realizes that reality is not like life is in Mexican soap operas [...] (taken from David's response paper, April 28, 2011)

Data demonstrates that the aspect of knowledge proposed by Byram to foster intercultural competence was acquired by EFL learners through the reading of multicultural pieces in English language.

Themes related to the aspect of skills

a. Questions and class discussion allow learners to discover content reflected in the multicultural reading (skills of discovery). 
Learners reported in the interviews and journals that the multicultural selections had allowed them to discover cultural content that they had never paid attention to or had never known before. Interestingly, they considered that they had developed the skill of discovery during class discussion:

[Maria] I had a better knowledge about what my classmates thought of the short stories. I clarified many ideas when we compared our answers with other classmates. We could open our minds by trying to answer questions, taking into account other possible meanings, and how we can understand an idea from different perspectives. (Interview, May 31, 2011)

This comment reveals that students developed the skill of discovery as they were eager to find deep meaning in the stories. This fact reveals that the skill of discovery can be attained in EFL because learners are challenged to read between the lines and find information that they had probably not paid attention to in the readings.

\section{b. Learners were able to interpret cultural and literary contents when reading multicultural texts (skill of interpreting).}

Data show learners were able to develop the skill of interpreting. Part of this skill has been implicitly reflected in the previous data since, as explained in the theoretical framework, the skills of discovery, of interpreting, and of acquiring knowledge are interconnected and inseparable aspects, one depending on the other. However, it is important to clarify that the skill of interpreting implies conveying, explaining, and constructing the meaning of what has been discovered.

One of the most significant findings of this study is that participants actually were able to interpret literary content in English. For instance, learners interpreted and explained the concept of the American Dream presented in the story "The First seven Years." Learners commented that the American dream had been changed from a humanistic view to a materialistic conception because success was based on having money and power while aspects such as values, moral, and hard work had been put aside. Another student interpreted from the story that Malamud wanted to show that the American Dream could only be achieved by white Americans since attitudes of racism and inequality suggested that the American Dream was not attainable for all, as it happened with the character Sobel in the short story (field notes, April 28, 2011). These examples prove that learners were encouraged to develop the skill of interpreting.

Additionally, participants' opinions in the interview demonstrate that they developed interpretative skills through the literary texts as can be seen in these units of analysis:

[Maria] [...] In the case of "The First Seven Years," we interpreted the story in terms of family relationships, women's role in society, and also the techniques of other writers that influenced Malamud. (Interview, May 31, 2011)

[Alex] It's good to try to reach different interpretations of the literary texts. It's perfect because sometimes or at least some time ago, I only used to read books in a superficial level. I used to say "OK, that story is good," but I didn't try to find what the deeper meaning was. But, I have realized in this course that it is not just reading, but understanding and interpreting the short stories. (Interview, May 31, 2011).

Thus, learners valued the fact that they had been able to interpret the literary texts more carefully than they had done in previous courses and that reading literature implied a process of interpreting and understanding texts in a deeper way. This fact was a meaningful discovery in this research because learners themselves reported they had developed the skill of interpreting as an essential part of the reading process. Therefore, it allowed them to develop ICC by means of making sense of significant crosscultural connotations, values, and literary issues contained in the literary texts.

c . Learners were able to compare cross-cultural and literary content when reading multicultural texts (skill of comparing).

Data also show how learners developed the skill of comparing. For instance, when discussing 
“Woman Hollering Creek," learner compared chauvinism in Mexico with other countries. One student argued that Mexicans were well-known for being extremely chauvinist around the world. However, in her opinion, men in South America and men in almost all parts of the world were, at some degree, chauvinists (field notes, April 20, 2010). Learners also compared Cleófilas to the two other female characters in the story, Felice and Graciela. Learners concluded that while Cleófilas was subjugated to her patriarchal Mexican traditions, Graciela and Felice had been able to become independent and happy as they have rejected them and lived in the U.S. (response paper, April 28, 2011). The comparison of these characters allowed them to identify different female roles in society. The same happened when learners compared Maggie, Mama, and Dee's concept of the quilts in "Everyday Use." Learners discussed that while Dee conceived the quilts as decorative and fashionable artifacts to preserve her African-American heritage, Maggie and Grandma appreciated them as useful and functional elements to be used as part of their daily cultural practices. The same happened when learners compared Maggie's simple life as opposed to Dee's materialistic and extravagant lifestyle. These differences allowed them to understand that Dee had refused to keep her African-American cultural heritage while Maggie has preserved it (Field notes, May 19, 2011). Students also referred to the skill of comparing in the interviews:

[Camilo] I think the process we used worked for me because it's better to read the text first without any influence, and then learn about the author and about the context. Then, you can understand, connect, and compare your personal response to the author's ideas. (Journal, May 19, 2011).

Thus, as intercultural learners, participants accepted they had compared issues among their own culture and other cultures when reading the literary pieces. This allowed them to deal with cultural diversity and to understand cultural identities.

\section{Themes related to the aspect of attitudes}

\section{a. Multicultural literary texts enhance EFL lear- ners' positive attitudes to diverse intercultural expressions.}

Most of students' opinions in the journals, the interviews, and the field notes are loaded with positive attitudes toward the reading of multicultural literary texts. EFL learners reflected about different situations of indifference, discrimination, and marginalization that allowed them to become more aware of the need to develop the competence to understand, respect, and accept people that are different from our own cultural background. For instance, learners developed empathy for characters such as Mama and specially Maggie in "Everyday Use," Sobel in "The First Seven Years," and Cleófilas in "Woman Hollering Creek." Learners understood that those fictional characters represented many real human beings around the world who were victims of hatred and intolerance, but who confronted life with tenacity and determination and proved being dignified individuals.

Learners also reflected in their journals about the necessity to create positive intercultural attitudes and the need to become open-minded to other views and beliefs.

[Judy] (S3) I not only developed interpretative skills, but empathy and tolerance because I started to get identified with minorities and I acquired a more critical position toward discriminatory and racist policies. (Journal, May 19, 2011).

[Omar] I consider I have been more open-minded by trying to understand people's behaviors and thought without judging them. Furthermore, I have been more curious about cultures through the short stories. (Journal, May 19, 2011).

These units of analysis demonstrate that learners recognized that the topics discussed in class helped them to create and strengthen responsiveness, sensitivity, and understanding to aspects of culture and literature. The creation of attitudes such as empathy, curiosity, tolerance, and openness constitutes one of the major achievements in this research experience. 
Participant created positive attitudes not only to all the literary texts read in class, but to literature in general.

[Jimena] I think that when you study literature and more specifically when you criticize literature, you have to read and study social and cultural aspects to understand the literary text. A text is not only composed by language, but it is full of social and cultural content provided by the writer. (Interview, May 31, 2011).

In consequence, learners in this course developed positive attitudes to understand and appreciate cultural context through the reading of the literary texts selected.In general, they also recognized they developed ICC at the levels of knowledge, skills, and attitudes through the means of multicultural literature.

\section{Limitations of the experience}

Learners admitted the first readings had been difficult because they contained new vocabulary:

[Adriana] Some of the texts have been difficult because of the vocabulary. So, we have to look up and understand words in context, but, after all, it is not that difficult. It is very enriching for me as a student to read these types of texts, to comment, and to compare our ideas with others. (Interview, May 31, 2011).

However, learners manifested that the later readings had been easier because they were already familiar with the methodology. Others admitted that they had taken more time to read the stories than with other kinds of materials. Some learners affirmed that when they didn't know the meaning of a word, they tried to understand it from context. Although the stories were somewhat challenging to read, students reported they enjoyed them due to the complementary material and the pedagogical support provided.

\section{Conclusions of the study}

This qualitative research has justified the reasons of using multicultural literatureas a motivating material to help EFL learners develop ICC. The findings obtai- ned from students' opinions show that they became critical readers at the level of their own capacities as they were encouraged to read, interpret, and discuss diverse literary selection in a foreign language.

One of the most salient findings is that learners became aware of the aspects that define ICC and reported in their comments the knowledge they acquired, the skills they developed, and the attitudes they created when they read multicultural selections. Their level of awareness as shown in their views became a main achievement in this study because learners' ability to be conscious of their own learning process and of the benefits of reading multicultural literature provide insightful arguments to validate its incorporation in language teaching.

Results indicate that participants discussed critically deep elements of culture such as discrimination, marginalization, generation gaps, gender and social inequality, and imposed cultural constructs. These topics led them to observe that issues of culture are not always static and homogeneous, but rather transformative and might cause dissimilar positions and reactions. That is to say, not everybody agrees with their own cultural or the target cultural system. Resistance is part of the process of shaping cultures.

This study also shows the importance of taking into account students' opinions about teaching procedures, materials, and academic processes used in the EFL classroom. Their voices not only contribute to improve teaching practices, but constitute an important viewpoint to address qualitative research because they help teachers to find more meaningful and pedagogical understanding to improve their teaching profession.

\section{References}

Amer, A. (2003). Teaching EFL/ESL Literature. The Reading Matrix, 2(3), 238-245.

Atkinson, D. (1999). TESOL and culture. TESOL Quarterly, 4(33), 625-654.

Banks, J. (2004). Teaching for social justice, diversity, and citizenship in a global World. The Educational Forum, 68, 289-298. 
Barletta, N. (2009). Intercultural competence: another challenge. Profile: Issues in Teacher's Professional Development, 11, 143-158.

Byram, M., Nichols, A. \& Stevens, D. (Eds.) (2009). Developing Intercultural Competence in Practice. Exeter, England: Cromwell Press.

Byram, M. (1997). Teaching and assessing intercultural communicative competence.

Clevedon: Multilingual Matters.

Cai, M. (2000). Multicultural literature for children and young adults: Reflections on critical issues. Westport, CT: Greenwood Press.

Candlin, C., Hall, D. \& Hall, J. (2002). Teaching and researching language and culture. Esses, England: Longman.

Carter, R. \& McRae, J. (Eds.) (1996). Language, literature and the learner. London: Longman.

Carter, R. \& Long, M. (1991). Teaching literature. London: Longman.

Cisneros, S. (1992). Woman Hollering creek and other stories. New York: Vintage Books.

Dogankay-Aktuna, S. (2005). Intercultural communication in English language teacher education. ELT Journal, 99-107.

Freeman, L. (1998). Doing teacher-research: From inquiry to understanding. Boston: Heinle \& Heinle.

Hames-Garcia, M. (2003). Which America is ours?: Marti's 'Truth' and the Foundation of 'American Literature.' MFS Modern Fiction Studies, 1(49), 19-53.

Kachru, B. (1992). Ed. The other tongue: English across cultures. 2nd ed. Illinois: University of Illinois.

Kramsch, C. (2001). Content and culture in language teaching. Oxford: Oxford UP.

Kubota, R. (2004). Critical multiculturalism and second language education. In B. Norton \& K. Toohey (Eds.), Critical pedagogies and language learning (pp. 30-52). Cambridge: Cambridge University Press.

Lázár, I. (2003). Incorporating intercultural communicative competence in language teacher education. Council of Europe: European Centre of Modern Languages.

McGee, C. \& Banks, J. (1995). Equity Pedagogy: An Essential Component of

Multicultural Education. Theory and Practice, 31(34), 52-158.

Malamud, B. (1989). The first seven years. The magic barrel. New York: Farrar, Straus, \& Giroux, (pp. 3-16)
McKay, S. (2001). Literature as content for ESL/EFL. In M. Murcia (Ed.), Teaching Englishes a Second/ Foreign Language (pp. 319-331). Boston, MA: Heinle \& Heinle.

Paige, M., Jorstad, Siaya, Klein, F. Colby, J. (2003). Cultural learning in language education: A review of literature. Culture as the Core: Perspectives on Culture in Second Language Learning, 1-65.

Patton, M. (2002). Qualitative research and evaluation methods [ $3^{\text {rd }}$ ed.]. California: Sage Publications, Inc.

Pratt, M. (2002). Professing in the contact zone: Bringing practice and theory together. National Council of Teachers of English, 1-18.

Spencer-Oatey, H. (2008). Culturally speaking culture, communication and politeness theory. London: Continuum International Publishing Group.

Stake, R. (2010). Qualitative research: studying how things work. New York: The Guilford Press.

Trujillo, F. (2002). Toward interculturality through language teaching: Argumentative discourse. Cauce, revista de filología y su didáctica, 25,103-119.

Walker, A. (1995). Everyday use. In love and trouble: Stories of black women. New York: Harvest Book Harcourt. 